\title{
Comparative morphometric characters of gladiator swimming crab Callinectes pallidus (Rochebrune, 1883) (Crustacea: Decapoda) from two coastal areas in Lagos Southwest Nigeria
}

\section{Gabriel Olarinde Mekuleyi*, Emmanuel Olugbenga Lawson and Kafayat Adetoun Fakoya}

Department of Fisheries. Lagos State University. Ojo. Lagos. Nigeria. *Email:gabrielmekuleyi@gmail.com.

\begin{abstract}
The present study compared the morphometric characters of Callinectes pallidus (Rochebrune, 1883) (Crustacea: Decapoda) collected from two coastal areas in Lagos, Nigeria, as a measure of investigating the degree of susceptibility of the species to environmental stress. Thirteen different morphometric characters (distances) which included eye cavity length (ECL), inter-orbital distance (IOD), medial peduncle width (MPW), carapace total length (CTL), carapace total width (CTW), carapace final width (CFW), width of the joining between the propodus and the movable chela thigh (PCT), chela dactylus length (CDL), first movable chela width (FMW), 2nd, 3rd and 4th pereiopod merus width (PMW), merus length (ML), abdomen total length (ATL) and abdomen first suture width (AFW) were measured with precision calliper with an accuracy of $0.01 \mathrm{~mm}$. Differences in mean morphometric distance were tested with T-test and Z-test while the standardized values were examined with fisher's linear discriminant function. 12 morphometric characters except MPW showed a significance different $(p<0.05)$ for male crabs between the sites while FMW only indicated no sites differences $(p>0.05)$ in female crabs examined. All the statistical tools employed clearly shown a great distinction in the growth of the crabs across the two sites. Therefore, this preliminary study concluded that $C$. pallidus from site 2 (Agbara) are more susceptible to environmental stress. However, further research is required to identify these environmental stressors.
\end{abstract}

Keywords: Crabs; Growth; Susceptible; Environmental stress.
Received

May 7, 2017

Accepted

June 27, 2017

Released June 30, 2017

Open Acess

Full Text Article

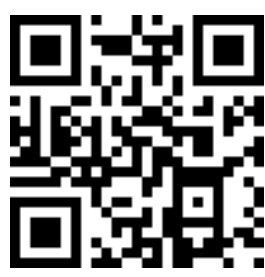

ORCID

(1) 0000-0002-1030-2518

Gabriel Olarinde

Mekuleyi

(D) 0000-0002-3014-0499

Emmanuel Olugbenga

Lawson

D $0000-0001-8308-7568$

Kafayat Adetoun

Fakoya

\section{Introduction}

Callinectes pallidus (Rochebrune, 1883) (Crustacea: Decapoda) is an economically viable crab in Nigeria which is often in abundance for sales in the open markets throughout the coastal towns of Lagos, southwest, Nigeria. This species inhabits both estuaries and inshore waters, habitats often susceptible to contamination from anthropogenic sources (Davis et al., 2005). Studies have been carried out on C. pallidus from different water bodies in Nigeria, which divulged its growth pattern per sex and its ability to bioaccumulate toxicants and endocrine disrupting 
chemicals. Such reported studies include the work of Aruke et al. (2012), Aderinola et al. (2013), Daka and Ugbomeh (2013), Clarke et al. (2013).

However, to the best of our knowledge, no findings up to date, has been reported in Nigeria on the morphometric characters of $C$. pallidus from Iwaya (in Lagos Lagoon) and Agbara (in Ologe Lagoon). Therefore, this preliminary study aims at comparing the morphometric distances (characters) of $C$. pallidus from Iwaya and Agbara, as a possible measure of the degree of susceptibility to environmental stress.

\section{Materials and methods}

\section{Study areas}

The study site 1 (Iwaya) in Lagos Lagoon and site 2 (Agbara) in Ologe Lagoon are as shown in Figure 1. Iwaya is a highly populated town, located east of Lagos Lagoon and it's surrounded by several other densely populated towns such as Surulere, Yaba, Ijora and Kirikiri. The Lagoon is the main channel of waste disposal for Iwaya people. Majority of the people at Iwaya are Ilajes whose occupations are either traders, artisans, fish mongers or fishermen.

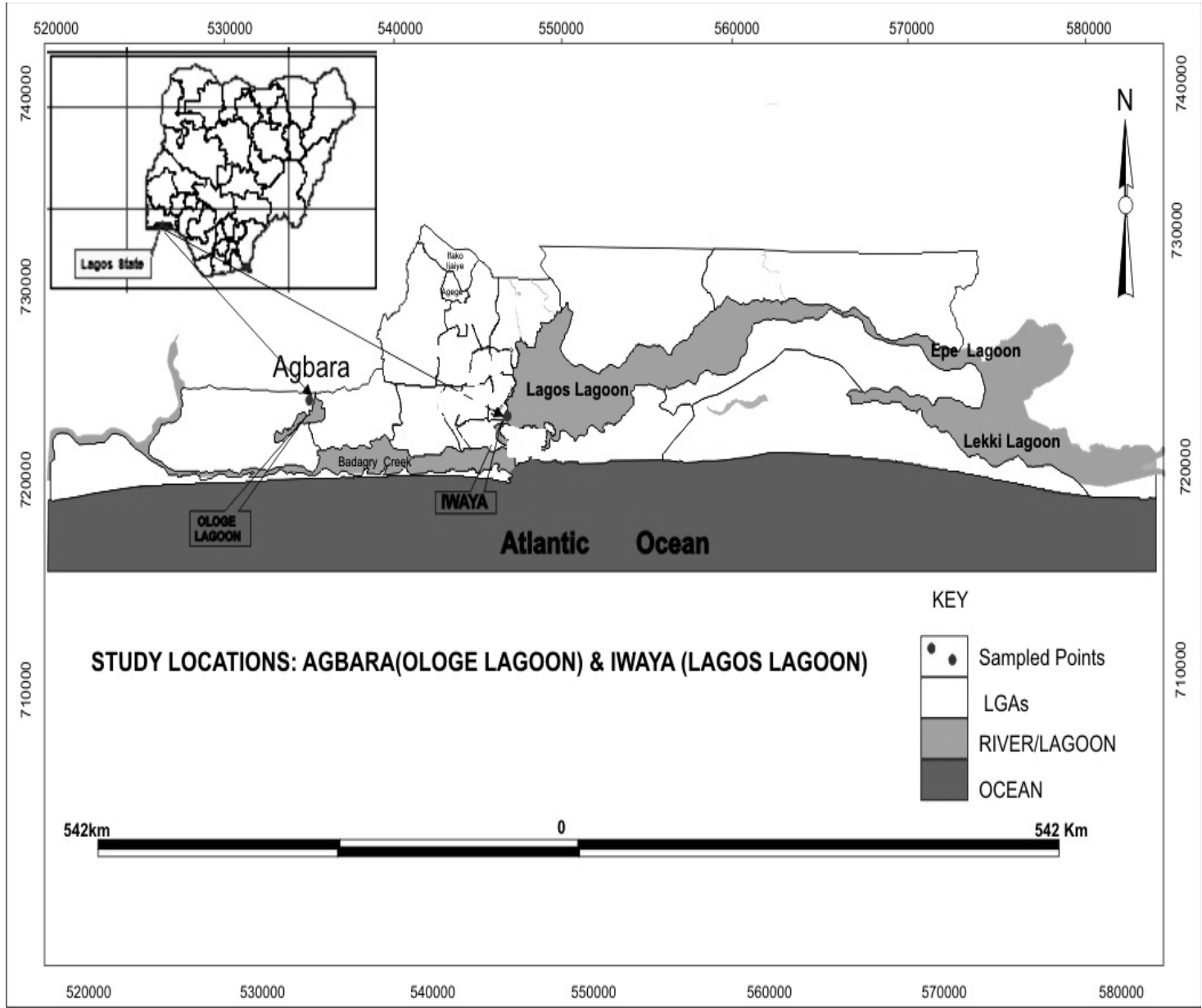

Figure 1. Map of Lagos Lagoon complex showing site 1 (Iwaya) and site 2 (Agbara). 
Agbara, site 2, is an industrial area as well as residential with fewer population in comparison to Iwaya. It is located at the West of Ologe Lagoon along Badagry express way. Most of the population are industrialist while fewer are Ogus and Ewes fisher-folks.

\section{Collection of specimens}

A total of 560 specimens of C. pallidus, consisting of 280 male and 280 female crabs at each site were randomly and purposively collected alive from fisher folks at Iwaya water side (In Lagos Lagoon) and Agbara water side (In Ologe Lagoon) between April and October, 2012. Specimens were sorted (purposively) by sex using the observation of the characteristics abdomen shapes and the appearance of the first 2 pairs of pleopod (modified of gonopods in males). Samples were frozen soon after collection and defrosted after four days for laboratory analyses, to ensure that all crabs were analysed following a similar period of freezing.

\section{Measurement of the morphometric characteristics}

Measurements generally followed the description by Duarte et al. (2008). Thirteen (13) different morphometric characters were measured and these included: Eye Cavity Length (ECL), InterOrbital Distance (IOD), Medial Peduncle Width (MPW), Carapace Total Length (CTL), Carapace Total Width (CTW), Carapace Final Width (CFW), Width of the joining between the Propoduc and the Movable Chela Thigh (PCT), Chela Dactylus Length (LDL), First Movable Chela Width (FMW), 2nd, 3rd and 4th Pereiopod Merus Width (PMW), Merus Length (ML), Abdomen Total Length (ATL) and Abdomen First suture Width (AFW). All the morphometric distances (characters) were measured with measuring tape and precision calliper with an accuracy of $0.01 \mathrm{~mm}$.

\section{Statistical analysis}

The differences of means morphometric distances of the crabs between the two sites were tested with t-test at significant level of $p<0.05$, while the degree of significance were validated through Z-test.

The carapace total length was used as a standard length to determine the coefficient of variation of other morphometric characters for the two sites.

Because the goal of morphometrics is the study of size and shape variation, one of the basic steps often required is standardization for size (Avsar, 1994). Thus, the raw data were standardized according to description of Avsar (1994) to bring all the variables into proportions with one another and to be approximately equivalent to adjust for the disparity in the variable sizes. Afterward, the standardized values were tested with Fisher's Linear discriminant function and Wilk's Lambda statistics.

\section{Results}

Table 1 showed that the differences in the morphometric distances of male $C$. pallidus from Iwaya against the males from Agbara were statistically significant $(p<0.05)$ for 12 morphometric distance with the exemption of MPW ( $p>0.05)$. Furthermore, the distinction in the morphometric distances of the females C. pallidus from Iwaya against the females from Agbara were not significant ( $p>0.05$ ) only for IOD, CTW, CFW and ATL.

The Z-test affirmed that all the 12 morphometric distances recorded among the male crabs are highly significantly different but MPW is greatly insignificantly different. Similarly, the differences in the morphometric distances among the female crabs of the two sites are highly significantly different except in FMW which showed that the two samples are marginally different. 
Table 1. Summary of the morphometric measurements of Callinetes pallidus from Iwaya and Agbara.

\begin{tabular}{lcccc}
\hline \multirow{2}{*}{$\begin{array}{c}\text { Morphometric } \\
\text { Characters }\end{array}$} & \multicolumn{2}{c}{ Iwaya } & \multicolumn{2}{c}{ Agbara } \\
\cline { 2 - 5 } & Male $(\mathrm{n}=140)$ & Female $(\mathrm{n}=140)$ & Male $(\mathrm{n}=140)$ & Female $(\mathrm{n}=140)$ \\
\hline ECL & $54.84 \pm 0.51$ & $50.78 \pm 0.47$ & $49.53 \pm 0.39$ & $47.08 \pm 0.39$ \\
IOD & $24.08 \pm 0.22$ & $23.48 \pm 0.25^{\mathrm{a}}$ & $22.11 \pm 0.36$ & $18.23 \pm 0.25^{\mathrm{a}}$ \\
MPW & $16.67 \pm 0.29^{\mathrm{a}}$ & $17.52 \pm 0.25$ & $19.24 \pm 0.28^{\mathrm{a}}$ & $16.23 \pm 0.30$ \\
CTL & $108.84 \pm 0.90$ & $116.04 \pm 0.97$ & $102.29 \pm 1.67$ & $98.30 \pm 1.62$ \\
CTW & $63.00 \pm 0.52$ & $65.08 \pm 0.54^{\mathrm{a}}$ & $52.9 \pm 0.91$ & $47.00 \pm 0.74^{\mathrm{a}}$ \\
CFW & $36.04 \pm 0.33$ & $41.50 \pm 0.34^{\mathrm{a}}$ & $27.94 \pm 0.54$ & $31.00 \pm 0.57^{\mathrm{a}}$ \\
PCT & $11.94 \pm 0.43$ & $11.14 \pm 0.27$ & $9.82 \pm 0.47$ & $7.87 \pm 0.19$ \\
CDL & $33.92 \pm 0.49$ & $29.20 \pm 0.55$ & $24.88 \pm 0.63$ & $21.15 \pm 0.09$ \\
FMW & $8.14 \pm 0.19$ & $8.24 \pm 0.17$ & $5.59 \pm 0.15$ & $7.46 \pm 0.27$ \\
PMW & $18.66 \pm 0.35$ & $16.45 \pm 0.29$ & $12.35 \pm 0.30$ & $12.30 \pm 0.27$ \\
ML & $44.30 \pm 0.57$ & $34.74 \pm 0.63$ & $32.20 \pm 0.93$ & $26.69 \pm 0.42$ \\
ATL & $45.80 \pm 0.38$ & $45.88 \pm 0.39^{\mathrm{a}}$ & $38.64 \pm 0.63$ & $36.69 \pm 0.45^{\mathrm{a}}$ \\
AFW & $41.38 \pm 0.38$ & $42.26 \pm 0.40$ & $34.52 \pm 0.64$ & $34.30 \pm 0.51$ \\
\hline
\end{tabular}

ECL = Eye Cavity Length, IOD = Inter Orbital Distance, MPW = Medial Peduncle Width, CTL = Carapace Total Length, CTW $=$ Carapace Total Width, CFW $=$ Carapace Final Width, PCT $=$ Width of the Joining Between the Propodus and the Movable Chela thing, CDL = Chela Dactylus Length, FMW = First Movable Chela Width, PMW $=2^{\text {nd }}, 3^{\text {rd }}$ and $4^{\text {th }}$ Pereiopod Merus Width, ML $=$ Merus Length, ATL $=$ Abdomen Total Length and AFW = Abdomen First Suture Width.

The summary of the ratios of other morphometric distances in Carapace Total Length (CTL) of $C$. pallidus from the sites are presented on Table 2. The ratio for the male crabs from the sites were distinct from one another with the exclusion of $\frac{\mathrm{ECL}}{\mathrm{CTL}}, \frac{\mathrm{IOD}}{\mathrm{CTL}}$, and $\frac{\mathrm{AFW}}{\mathrm{CTL}}$.

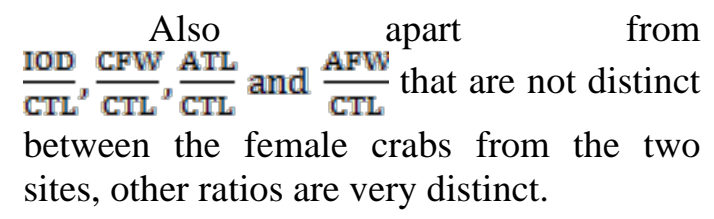

Table 2. The ratios of other morphometric distances in carapace total length of Callinetes pallidus from Iwaya and Agbara

\begin{tabular}{lcccc}
\hline \multirow{2}{*}{ Morphometric Ratio/Variation } & \multicolumn{2}{c}{ Male } & \multicolumn{2}{c}{ Female } \\
\cline { 2 - 5 } & Iwaya & Agbara & Iwaya & Agbara \\
\hline ECL:CTL & $1: 2$ & $1: 2$ & $1: 2$ & $1: 2$ \\
IOD:CTL & $1: 5$ & $1: 5$ & $1: 5$ & $1: 5$ \\
MPW:CTL & $1: 7$ & $1: 5$ & $1: 7$ & $1: 6$ \\
CTW:CTL & $1: 2$ & $1: 2$ & $1: 2$ & $1: 2$ \\
CFW:CTL & $1: 3$ & $1: 4$ & $1: 3$ & $1: 3$ \\
PCT:CTL & $1: 9$ & $1: 10$ & $1: 10$ & $1: 12$ \\
CDL:CTL & $1: 3$ & $1: 4$ & $1: 4$ & $1: 5$ \\
FMW:CTL & $1: 13$ & $1: 18$ & $1: 14$ & $1: 13$ \\
PMW:CTL & $1: 6$ & $1: 8$ & $1: 7$ & $1: 8$ \\
ML:CTL & $1: 2$ & $1: 3$ & $1: 3$ & $1: 4$ \\
ATL:CTL & $1: 2$ & $1: 3$ & $1: 3$ & $1: 3$ \\
AFW:CTL & $1: 3$ & $1: 3$ & $1: 3$ & $1: 3$ \\
\hline
\end{tabular}

ECL $=$ Eye Cavity Length, IOD $=$ Inter Orbital Distance, MPW $=$ Medial Peduncle Width, CTL $=$ Carapace Total Length, CTW $=$ Carapace Total Width, CFW $=$ Carapace Final Width, PCT $=$ Width of the Joining Between the Propodus and the Movable Chela thing, CDL = Chela Dactylus Length, FMW = First Movable Chela Width, PMW $=2^{\text {nd }}, 3^{\text {rd }}$ and $4^{\text {th }}$ Pereiopod Merus Width, ML $=$ Merus Length, ATL $=$ Abdomen Total Length and AFW = Abdomen First Suture Width. 
The fisher's linear discriminant function coefficient of the two sites (Iwaya and Agbara) is shown in Table 3. All the morphometric distances except PMW and PCT had a very high coefficient for both sites. The test of equality of the group means through Wilk's Lambda is presented in Table 4. The smaller values of Wilk's Lambda indicate the variables are better at discriminating between groups. The table also suggests that MPW is least at discriminating between groups while CTL and CTW are the best.

Table 3. Fisher’s linear discriminant functions coefficient.

\begin{tabular}{lcc}
\hline & \multicolumn{2}{c}{ Site } \\
\cline { 2 - 3 } & Site $\mathbf{1}$ & Site 2 \\
\hline ECL & 215.575 & 224.665 \\
IOD & 31.212 & 26.551 \\
MPW & 68.120 & 72.339 \\
CTL & 135.883 & 117.211 \\
CFW & 87.972 & 70.476 \\
PCT & -20.778 & -22.893 \\
CDL & 61.986 & 46.698 \\
FMW & 38.427 & 33.869 \\
PMW & 13.921 & 9.066 \\
ML & 53.248 & 38.401 \\
ATL & 58.458 & 50.068 \\
AFW & 54.883 & 48.982 \\
(Constant) & -648.931 & -531.285 \\
\hline
\end{tabular}

Table 4. Tests of Equality of Group Means.

\begin{tabular}{lccccc}
\hline & Wilk's Lambda & F & df1 & df2 & Sig. \\
\hline ECL & .774 & 162.479 & 1 & 558 & .000 \\
IOD & .718 & 219.124 & 1 & 558 & .000 \\
MPW & .984 & 9.272 & 1 & 558 & .002 \\
CTL & .434 & 726.248 & 1 & 558 & .000 \\
CTW & .434 & 726.248 & 1 & 558 & .000 \\
CFW & .512 & 531.311 & 1 & 558 & .000 \\
PCT & .818 & 124.336 & 1 & 558 & .000 \\
CDL & .460 & 654.908 & 1 & 558 & .000 \\
FMW & .890 & 68.856 & 1 & 558 & .000 \\
PMW & .575 & 412.994 & 1 & 558 & .000 \\
ML & .532 & 489.979 & 1 & 558 & .000 \\
ATL & .724 & 212.900 & 1 & 558 & .000 \\
AFW & .600 & 371.487 & 1 & 558 & .000 \\
\hline
\end{tabular}

The accuracy of the model in separating site 1 from site 2 was cross validated as shown in Table 5. And this result showed that $98.4 \%$ of the cross- validated grouped cases are correctly classified while $1.6 \%$ are wrongly classified. 
Table 5. Classification results ${ }^{\mathrm{a}, \mathrm{c}}$.

\begin{tabular}{|c|c|c|c|c|c|}
\hline & & \multirow{2}{*}{ Site } & \multicolumn{2}{|c|}{ Predicted Group Membership } & \multirow{2}{*}{ Total } \\
\hline & & & Site 1 & Site 2 & \\
\hline \multirow{6}{*}{ Original } & \multirow{2}{*}{ Count } & Site 1 & 280 & .0 & 280 \\
\hline & & Site 2 & 9 & 271 & 280 \\
\hline & \multirow{2}{*}{$\%$} & Site 1 & 100.0 & .0 & 100.0 \\
\hline & & Site 2 & 3.2 & 96.8 & 100.0 \\
\hline & \multirow{2}{*}{ Count } & Site 1 & 280 & .0 & 280 \\
\hline & & Site 2 & 9 & 271 & 280 \\
\hline \multirow{2}{*}{ Cross-validated $^{\mathrm{b}}$} & \multirow{2}{*}{$\%$} & Site 1 & 100.0 & .0 & 100.0 \\
\hline & & Site 2 & 3.2 & 96.8 & 100.0 \\
\hline
\end{tabular}

${ }^{\mathrm{a}} 98.4 \%$ of original grouped cases correctly classified; ${ }^{\mathrm{b}}$ Cross validation is done only for those cases in the analysis. In cross validation, each case is classified by the functions derived from all cases than that case; c. $98.4 \%$ of cross validated grouped cases correctly classified.

\section{Discussion}

The results of the morphometric distances of male $C$. pallidus from Iwaya being significantly greater than the males counterpart from Agbara, agreed with the report of Brian et al (2006), Davis et al. (2005) and Møller (1998) that environmental disturbances can induce changes in same organism. The outstanding chela dimensions such as chela dactylus length (CDL) and the first movable chela width (FMW) of the male crabs from Iwaya which grew better than those males from Agbara also supported the report of Masunari and Swiech-Ayoub (2003).

Similarly, highly significantly bigger females recorded at Iwaya against Agbara also buttressed the findings of Aderinola et al. (2013) which reported that the females $C$. pallidus from Ojo Creek (a habitat often reported to be subjected to less anthropogenic disturbance) have viable morphometric distances. The ratios of the other morphometric distance to the carapace total length of the male and female C. pallidus from the two sites which revealed that those crabs from Iwaya grew better than crabs from Agbara, was also similar to the report of Brian (2005).

$98.4 \%$ of the cross-validated grouped cases being correctly classified in this study suggest that there is a clear distinction between the $C$. pallidus from the two sites. And this current finding was similar to the report of Murta (2000) and Tudela (1999). The Wilk's Lambda analysis which affirm that all the variables except MPW discriminate significantly between groups, also indicate a relatively high degree of variance in the means of the crabs from the two sites. And this similar result has been reported by Bolles and Begg (2000). The lowest coefficient recorded in PMW and PCT for both sites as shown by fishers discriminant function coefficient analysis, implies that these two morphological features are not strong enough to differentiate crabs of one site from the other.

In summary, this present study has provided important morphometric information that showed a distinct variation between C. pallidus from two coastal areas in Lagos, Nigeria. Therefore, it could be concluded that $C$. pallidus from site 2 are more susceptible to environmental stress. However, further research is pertinent to investigate these environmental stressors.

\section{References}

Aderinola, O.; Adeboyejo, A.; Clarke, E.; Kusemiju, V.A. study of length-weight relationship and condition factor of West African blue crab (Callinectes pallidus) from Ojo Creek, Lagos, Nigeria. American Journal of Research Communication, v. 1, No. 3, 102114, 2013. Available from: <http://www.usajournals.com/wp-content/uploads/2013/02/ 
Oluwatoyin2_Vol13.pdf>. Accessed on: Nov. 23, 2016.

Aruke, A.; Eggen, T.; Moder, M. Solid waste deposits as a significant source of contaminants of emerging concern to the aquatic and terrestrial environments: a developing country case study from Owerri, Nigeria. Science Total Environment, v. 438, p. 94-102, 2012. https://dx.doi.org/10.1016/j.scitotenv.2012.08.039

Avsar, D. A stock differentiation study of the sprat (Sprattus sprattus phalerius Risso) off the Southern Coastal of the Black Sea. Fish Resources, v. 19, p. 363-378, 1994.

Bolles, K. L.; Beggs, G. A. Distinction between silver hake (Merluccius bilinearis) stocks in US waters of the Northwest Atlantic based on whole otolith morphometrics. Fish Bulletin, v. 98, No. 3, p. 451-462, 2000. Available from: $<$ http://fishbull.noaa.gov/983/01.pdf $>$. Accessed on: Nov. 23, 2016.

Brain, J. V. Inter-population variability in the reproductive morphology of the shore crab (Carcinus maenas) evidence of endocrine disruption in a marine crustacean. Marine pollution Bulletin, v. 50, p. 410-416, 2005. https://doi.org/10.1016/j.marpolbul.2004.11.023

Brain, J. V.; Fermandes, T.; Ladle, R. J.; Todd, P.A. Pattern of morphological and genetic variability in UK population of the shore crab, Carcinus maenas Linnaeus, 1758 (Crustacea: Decapoda: Brachyura). Journal of Experimental Marine Biology and Ecology, v. 329, p. 47-54, 2006. https://doi.org/10.1016/j.jembe.2005.08.002

Clarke, E. O.; Aderinola, O. J.; Adeboyejo, O. A. Persistent Organochlorine Pesticides (POPs) in water, sediment, fin fish (Sarotherodon galiacus) and shell fishes (Callinectes pallidus) and Macrobranchium macrobranchium samples from Ologe Lagoos, Lagos, Nigeria. American Journal of Research Communication, v. 1, No. 6, p. 122135, 2013. Available from: <http://www.usajournals.com/wp-content/uploads/2013/05/

Clarke_Vol16.pdf $>$. Accessed on: Nov. 23, 2016.

Conde-Padin, P.; Grahame, J. W.; RolanAlvarez, E. Detecting shape differences in species of the Littorina saxatilus complex by morphometric analysis. J. Moll. Stud., v. 73, No. 2, $\quad$ p. 147-154, 2007. https://dx.doi.org/10.1093/mollus/eym009
Daka, E. R.; Ugbomeh, P. A. Polycylic aromatic hydrocarbons in sediment and tissue of Callinectes pallidus from Azuabie Creek of the Upper Bonny Estuary in the Niger Delta. Research Journal of Applied Sciences Engineering and Technology, v. 6, No. 14, p. 2594-2600, 2013. Available from: $<$ http://maxwellsci.com/print/rjaset/v6-25942600.pdf $>$. Accessed on: Nov. 23, 2016.

Davis, J. L. D.; Eckert, M. G.; Young-Williams, A. C.; Hines, A. H.; Zohar, Y. Morphological conditioning of a hatchery-raised invertebrate Callinectes sapidus to improve field survivorship after release. Aquaculture, v. 243, No. 1/4, p. 147-158, 2005. https://doi.org/10.1016/j.aquaculture.2004.09.027

Duarte, M. S.; Maia-Lima, F. A.; Molina, W. F. Interpopulational morphological analyses and fluctuating asymmetry in brackish crab Cardisoma guanhumi Latreille (Decapoda, Gecarcinidae) on the Brazilian North East coastline. Pan-American Journal of Aquatic Sciences, v. 3, No. 3, p. 294-303, 2008. Available from: <http://www.panamjas.org/ pdf_artigos/PANAMJAS_3(3)_294-303.pdf>.

Accessed on: Nov. 23, 2016.

Hsu, C. C.; Chang, H. C.; Liu, H. C. Sex variant morphomemtrics of the swimming crab, Portunus sanguinolentus (Herbst), from the waters off Northern Taiwan. Journal of Fisheries Society, v. 27, p. 175-185, 2000.

Masunari, S.; Swiech-Ayoub, B. P. Crescimento relativo em Uca leptodactyla Rathbum (Crustacea: Decapoda: Ocypodidae). Revista Brasileira de Zoologia, v. 20, No. 3, 487-491, $2003 . \quad$ http://dx.doi.org/10.1590/S010181752003000300020

Møller, A. P. Developmental instability as a general measure of stress. Advances in the Study of Behaviour, v. 27, p. 181-213, 1998. https://doi.org/10.1016/S0065-3454(08)60365-4

Murta, A. G. Morphological variation of horse mackerel (Trachurus trachurus) in the Iberian and North Africa Atlantic: implication for stock identification. ICES Journal of Marine Sciences, v. 57, No. 4, p. 1240-1248, 2000. https://dx.doi.org/10.1006/jmsc.2000.0810

Tudela, S. Morphological variability in a Mediterranean genetically homogeneous population of the European anchory, Eugraulis encrasicolus. Fish Resources, v. 42, No. 3, p. 229-243, 1999. https://dx.doi.org/10.1016/ S0165-7836(99)00052-1

License information: This is an open-access article distributed under the terms of the Creative Commons Attribution License, which permits unrestricted use, distribution, and reproduction in any medium, provided the original work is properly cited. 